\title{
ENTREVISTA COM ROBERTO ACÍZELO DE SOUZA ${ }^{1}$
}

1. O que você ensina quando ensina literatura? Qual a especificidade do ensino da literatura?

Ensino história da literatura e teoria da literatura, isto é, procuro tanto apresentaraosalunosa literatura sob a forma de uma narrativa - a sequência dos estilos históricos coletivos, a constituição dos cânones, os sistemas literários nacionais, a história intelectual dos autores, etc. — quanto sob a forma de um conceito - a ideia de literatura e seus desdobramentos, isto é, os gêneros literários, os modos de interpretação de textos, os métodos para estudo e análise do objeto literário, a diversidade das teorias sobre a literatura, etc.

Não sei se há alguma "especificidade", além dos elementos que mencionei no parágrafo anterior; talvez o fato de que o ensino da literatura integra um círculo mais amplo, o da educação estética.

2. O ensino da literatura tem um papel na construção do conhecimento? Qual é esse papel?

Sim, tem um papel; falei acima em "educação estética", e entendo por estética certa ramificação da filosofia que se fundamenta no pressuposto de que se pode construir conhecimento tanto pela via da pura razão quanto pela via da sensibilidade. Essa "via da sensibilidade" se concretiza \footnotetext{
de Males.
}

${ }^{1}$ Perguntas formuladas pelos organizadores do presente número da revista Remate 
sobretudo nas diversas artes, entre elas a literatura. Assim, ensinar e estudar literatura é refletir sobre um processo de produzir e veicular conhecimento, não um conhecimento propriamente demonstrável por processos de cálculos e experiências, mas certo saber das coisas movediças e complexas, que podemos compreender, sem exatamente conseguir explicar. Tais "coisas" não costumam ter nomes próprios, e assim chegamos até elas por meio de termos aproximativos, cujo conjunto constitui a linguagem das artes, que, no caso específico da literatura, é uma espécie de versão por assim dizer estilizante da linguagem verbal. Por exemplo, um poeta nosso, em síntese arrojada, serve-se da expressão "alma do Cosmos", para aproximativamente referir-se a essas "coisas", bem como ao modo de nos acercarmos delas: "Quando, à noite, o Infinito se levanta / À luz do luar, pelos caminhos quedos / Minha táctil intensidade é tanta / Que eu sinto a alma do Cosmos nos meus dedos!"2 "Sentir a alma do Cosmos nos dedos": eis um jeito ultraconcentrado de caracterizar o que pode fazer por nós a educação estética, ou o que podemos conquistar por meio dos "paroxismos da hiperestesia", no dizer superlativo do mesmo poeta.

3. Como documentos oficiais, como PCNs e PCN+, e a produção científica sobre ensino de literatura impactam ou impactaram a sua atuação?

Há muito tempo afastado do ensino fundamental e do médio, devo confessar a minha ignorância sobre documentos oficiais que na atualidade contêm as diretrizes para o ensino de literatura. Reconheço que não devia ignorá-los, uma vez que um aspecto básico do meu exercício profissional - em termos de alcance social e político, certamente o principal - é justamente contribuir para a formação de professores desses níveis, os quais, por definição, precisam conhecer tais documentos, e por isso um professor desses futuros professores também deveria interessar-se pelos PCNs e congêneres. Acrescento, porém, e não como atenuante, que entre meus colegas do magistério universitário grassa a mesma ignorância. Ora, isso é sintoma de um alheamento mútuo, envolvendo o corpo docente das universidades e os formuladores de políticas pedagógicas nacionais, e a responsabilidade por esse estado de coisas — obviamente nada bom para a educação brasileira - por certo deve ser divida, entre MEC, Conselho Nacional de Educação, Conselho de Reitores, associações científicas da área de letras.

\footnotetext{
${ }^{2}$ Augusto dos Anjos, no soneto "Ao luar".
} 
Sei, contudo, lendo matérias jornalísticas, que a nossa disciplina agora responde pelo nome pomposo de "Linguagens, códigos e suas tecnologias", tendo-se tornado, portanto, velha a novidade dos anos 1970 - "Comunicação e expressão" —, sem falar em designações como "Português" e "Literaturas", inteiramente deletadas no vocabulário da tecnocracia up to date que vem ditando tais "parâmetros".

Quanto a produção científica sobre ensino de literatura, também preciso confessar que conheço muito pouco, quase nada mesmo, e desconfio que o meu desconhecimento tem a ver com a pouca relevância dessa produção. Na minha atuação docente, por conseguinte, impacto zero desses elementos.

4. O ensino de literatura deve ser desvinculado do ensino de língua? Para reinserir a literatura na formação dos alunos da educação básica e fundamental, é interessante um professor de literatura com competências específicas?

Acho que o ensino de literatura não deve de forma alguma desvincularse do ensino de língua, e por isso, para a educação básica e fundamental, a formação dos professores deve harmonizar conhecimentos de língua e de literatura, não me parecendo pertinente a figura do "professor de literatura", dotado de competências específicas e distintas daquelas do "professor de língua”.

5. Na sua concepção, o que é material didático? As novas tecnologias contribuem, ou não, para o desenvolvimento de tais materiais?

Bem, para um professor de literatura o material didático por excelência são os textos, e assim, se as novas tecnologias favorecem o acesso a textos e contribuem para sua legibilidade material - e estou certo de que sim - , só podem constituir-se em ferramentas úteis para a pedagogia das letras. O problema é quando tais tecnologias extrapolam de sua condição de "ferramentas", virando o principal centro de interesse de todo o processo de ensino / aprendizagem, o que não é nada difícil, tendo em vista a sedução que exercem sobre todos nós. Dou um exemplo relacionado à questão: o governo fluminense vem de reinaugurar a Biblioteca Estadual, depois de uma ampla e demorada reforma; naturalmente, as novas instalações estão dotadas de equipamentos tecnológicos de toda ordem, que a propaganda oficial alardeou — existe 
até, no interior da Biblioteca, um espaço para relaxamento e atividades físicas, vejam só - , tendo-se calado, no entanto, sobre o que devia ser a principal atração de uma biblioteca - livros, certo? - , até porque nisso nada se investiu, e a dita Biblioteca Estadual, quanto a esse quesito, continuará pobre e deficiente como sempre foi.

6. A arte pura quer-se antieconômica. A indústria editorial atua para comercializar obras literárias como bens de consumo. De que modo a tensão entre esses dois polos chega às instituições escolares, em todos os níveis?

Não creio que a arte seja antieconômica, a menos que tenhamos um conceito muito estreito de economia. Mas vamos lá: um professor de literatura, entre suas estratégias didático-pedagógicas, deve estar atento àquilo que seus alunos estão lendo fora das prescrições dos programas escolares, isto é, supostamente obras pelas quais se interessam graças às promoções e à publicidade da indústria cultural, obras aliás, como todos sabemos bem, de ínfimo valor estético. E deve o professor de alguma forma capitalizar esse interesse dos alunos - mínimo que seja - pelo artefato livro, propondo-lhes não o abandono de suas leituras — digamos - "espontâneas", mas a extensão do repertório delas, e aí então deve entrar com suas prescrições de leitura, conduzindo os alunos ao cotejo crítico entre as obras momentosas e aquelas que de fato digamos sem vergonha e com o nosso conhecimento de causa - vale a pena ler.

7. Como você justificaria o investimento, por parte dos órgão públicos, no ensino da literatura? Qual seria a contrapartida social deste investimento?

Acho que nas respostas anteriores deixei implícito um encaminhamento para essa questão: se admitirmos que a educação é um processo de formação ampla, que inclui pelo menos três dimensões a técnico-científica, a ético-política e a estética - , concluiremos que, se quisermos preservar o ideal da formação plena, não podemos abrir mão da dimensão estética do processo educacional (tampouco das demais referidas, éclaro), e nessa dimensão certamentea literatura tem um lugar de destaque. Assim, acho que não podemos pensar a literatura como um item isolado do processo, que demandaria investimento financeiro específico 
visando a contrapartidas sociais igualmente específicas. O investimento público na educação há de visar ao que chamei "formação ampla ou plena", e a contrapartida social dos beneficiários do investimento - deduzo, pela formulação da questão, que se trata dos professores de literatura — deverá ser, antes de tudo, empenho na aquisição de competência técnica para o seu magistério, aí compreendida a consciência do seu papel específico - um operador da educação estética - no conjunto do processo. 